\title{
敗血症性肺塞栓症を合併した内頸静脈血栓症例
}

\author{
百島 尚樹・坪田 大・光澤 博昭・水見 徹夫

\section{A Case of Internal Jugular Vein Thrombosis with Septic Pulmonary Embolism}

\author{
Naoki Hyakushima, Hiroshi Tsubota, Hiroaki Mitsuzawa and Tetsuo Himi \\ (Sapporo Medical University)
}

\begin{abstract}
We report a case of Lemierre's syndrome, known as postanginal sepsis, which resulted in internal jugular vein thrombosis with septic pulmonary embolism.

A 53-year-old man was admitted with sore throat, fever, and left-sided neck pain and swelling. He had no chest pain and no dyspnea. Contrast enhanced CT scan of the neck revealed swelling of the left tonsil without abscess formation and low-density lumen with peripheral enhancement of the wall of the left internal jugular vein. Chest CT scan showed multiple round nodules with cavitation indicating the typical appearance of septic pulmonary embolism. There was no definite pleural effusion. Streptococcus intermedius was found on blood cultures. Based on the findings we diagnosed left internal jugular vein thrombosis with septic pulmonary embolism due to acute tonsillitis, and administration of intravenous antibiotics and heparin was started. Fever subsided by hospital day 7 , and the neck swelling and tenderness gradually reduced. Three months later, pulmonary nodules disappeared; however no blood flow of the internal jugular vein was noted, suggesting organization of the thrombus in the vein.

The treatment of internal jugular vein thrombosis is also discussed.
\end{abstract}

Key words : internal jugular vein thrombosis, septic pulmonary embolism, Lemierre's syndrome, Streptococcus intermedius, tonsillitis

はじめに

内頸静脈血栓症は抗生剂が普及する以前は頭頸部領域 の感染症の合併症としてしばしばみられていたが, 近年 では感染症に伴う症例は減少している。しかし今日でも いまだに感染症が誘因の本疾患は散見される。また急性 咽頭炎あるいは扁桃炎が誘因の化膿性血栓性静脈炎に 伴った敗血症は Lemierre's syndrome と呼ばれている. さらに本疾患は重大な合併症として肺塞栓症を引き起こ す可能性があり，迅速な診断と治療が必要である11. 今 回われわれは急性扁桃炎を契機として発症し，敗血症性 肺塞栓症を合併した内頸静脈血栓症の 1 例を経験したの で，若干の文献的考察を加光て報告する.
症例

症例 : 53歳, 男性.

主訴 : 発熱, 咽頭痛, 左頸部腫脤.

既往歷・家族歴 : 特記事項なし.

現病歷: 平成11年 2 月 15 日より発熱, 咽頭痛を訴光近 医を受診し，投薬を受けたが症状の改善はなかった。 2 月20日に他院を受診後, 頸部蜂窩織炎の診断にて抗生剂 点滴静注を施行されるも改善なく, 嚥下困難, 頸部腫脹 が増強してきたため 2 月 26 日当科紹介，入院となった.

入院時現症: 体温 $39.1^{\circ} \mathrm{C}$, 左頸部は腫脹し圧痛が あった．動脈血酸素飽和度は $92 \sim 96 \%$ と軽度低下してい たが，呼吸困難や胸痛はなかった．咽頭痛はあるも経口 
摂取は十分可能な状態だった。

血液学的所見 : CRP $21.9 \mathrm{mg} / \mathrm{dl}$, 白血球数 $13,800 / \mu 1$ と強い炎症反応がみられた。立たGOT $156 \mathrm{IU} / 1, \mathrm{GPT}$ $114 \mathrm{IU} / 1, \mathrm{BUN} 23 \mathrm{mg} / \mathrm{dl}, \mathrm{Cr} 1.2 \mathrm{mg} / \mathrm{dl}$ と軽度肝・腎 機能障害を示唆する異常值を示していた.

入院時画像所見：胸部単純X線写真で両肺野末梢に結 節性の異常陰影を認めた。頸部造影 CT では, 左口蓋扁 桃部に腫脹を認め, また左内頸静脈は内部低濃度で周囲 にリング状の造影効果を伴って括り, この内頸静脈の異 常像は頭蓋底から鎖骨下静脈合流部付近まで，扣よび左 外頸静脈にも及んでいた(図 1 )。胸部単純 CT では，両 肺野末梢に内部壞死による target sign や feeding vessel signを伴ら多発性の結節影を認めた。胸水貯留はみら れなかった(図 2 ).

前医での血液培養菌検査で Streptococcus intermedius

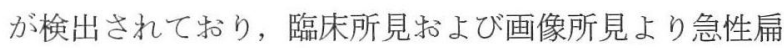
桃炎に続発した左内頸静脈血检症执よび敗血症性肺塞栓 症の合併と䛦断し，治療を開始した。

治療経過：2 月26日よりセファゾリンナトリウムの点 滴に加壳，同日よりへパリンナトリウム，3月1日より はダルテパリンナトリウムによる抗凝固療法，また 3 月 1 日より塩酸チクロピジンによる抗血小板療法を開始し た. 3 月 9 日より抗生剤をレボフロキサシン内服に変更 し，塩酸チクロピジンは9月30日まで継続投与した。ま た敗血症による多葴器不全兆候に対して 2 月26日より 3

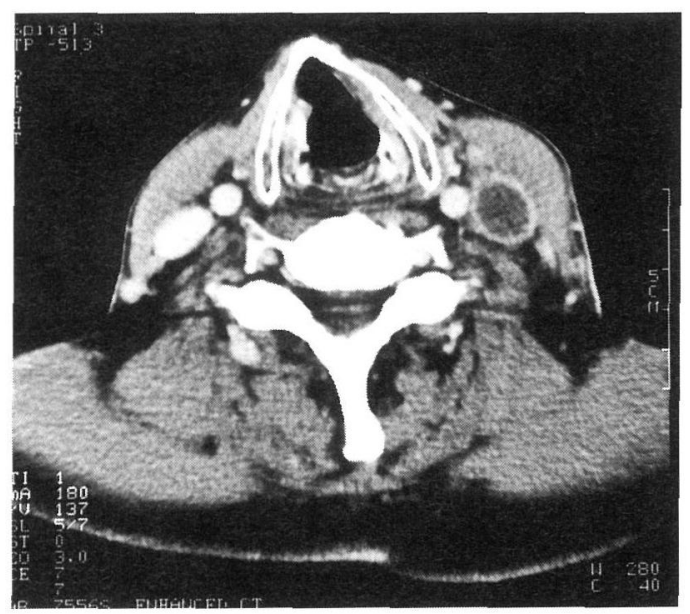

図 1 頸部造影 CT 所見 左内頸静脈は頭蓋底から鎖骨下静脈合流部付近まで,さ らに外頸静脈まで内部低濃度で周囲にリング状の造影効 果を併ら異常像を呈していた。

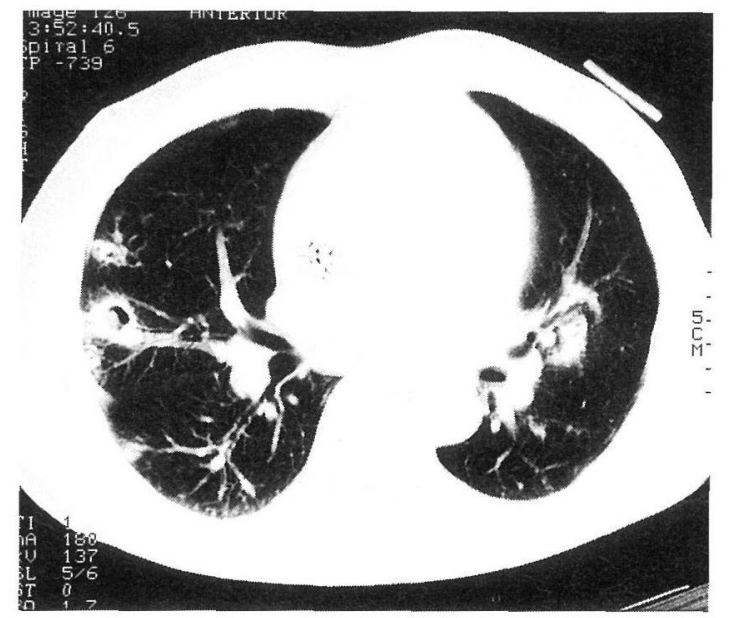

図 2 胸部単純 CT 所見

両肺野末梢に内部壊死による target sign p feeding vessel sign を伴ら多発性の結節影を認めた。胸水貯留はみ られなかった。

月10日までメシル酸ガベキサートを $2000 \mathrm{mg} /$ 日で持続 静注した.

治療開始後, CRP, 白血球数ともに順調に低下し，入 院7日目以降発熱はみられなかった。頸部腫脹扣よび圧 痛も徐々に軽快し, 退院となった 3 月 24 日には注消失 した。

6 月 3 日外来で撮影したCT では, 左内頸静脈に血栓 を思わせる所見は認めなかったが，血行の再開通はなく， 血栓の器質化による静脈閉塞が考光られた(図 3 ). 肺病 変は消失して和り，異常陰影は認めなかった(図 4).

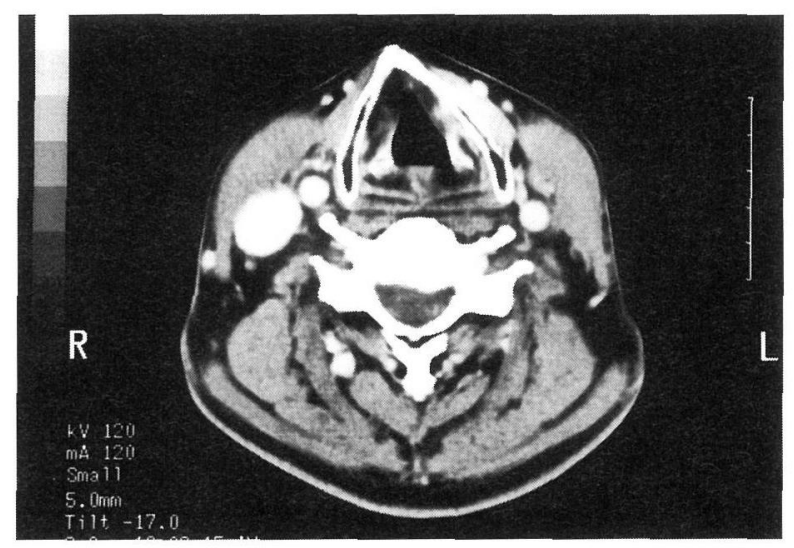

図 3 頸部造影 CT 所見(治療後) 左内頸静脈に血栓は認めなかったが，血行の再開通もみ られず，血栓の器質化による静脈閉塞が考えられた。 


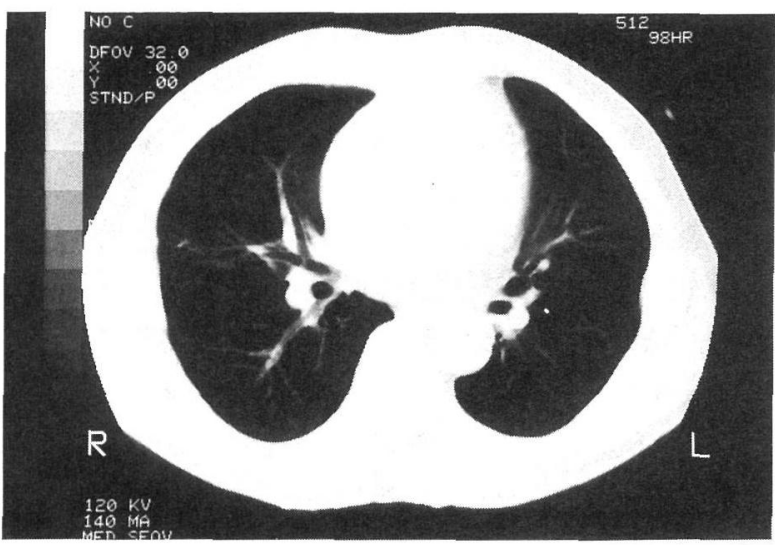

図 4 胸部単純 CT 所見 (治療後)

治療前にみられた多発珄結節影は消失して扮り, 異常陰 影は認めなかった。

\section{考察}

内頸静脈血栓症は1912年，Long2) ${ }^{2}$ とり扁桃周团膿 瘍に続発した症例が報告され, 以後頭頸部領域の感染症 に続発する症例が多数報告されたが, 抗生物質の発達し た近年では感染症に伴った症例は減少し，代わって中心 静脈カテーテル留置や薬物乱用による頻回の静脈注射が 誘因となる症例が増加している3．しかしながら，い未 だに急性咽頭炎を主とした頭頸部感染症が原因となった 症例がしばしば報告されている。

静脈血栓症発症には主として 3 つの要因, (1)血管内皮 損傷, (2)血流停滞・5っ血, (3)血液凝固能立進がいわれ て拈り，Virchow’s triadと呼ばれている。実際にはこ れらの要因が単独特よび複数重なり合って発症に至る ${ }^{31}$. 発症誘因となる病態としては, (1)局所感染症, (2)腫瘍や 膿瘍，血腫などによる血管の圧迫，(3)中心静脈カテーテ ル留置, (4)頻回の薬物注射による血管損傷(薬物乱用), (5)経口避妊薬使用や妊婦, 抗リン脂質抗体症候群, 悪性 腫瘍などの凝固系立進状態, などが挙げられる1)4) 6). 咽頭炎が原因の敗血症に伴う内頸静脈血栓症 (postanginal sepsis, septic thrombophlebitis) は Lemierre's syndromeと呼ばれて拉り, 自験例に相当する。悪性腫瘍 に伴ら凝固系充進状態は第证因子の増加とトロンボプラ スチンの産生増大のためと考えられている7). 原因不明 の内頸静脈血检症に遭遇した場合, 悪性腫瘍の存在を念 頭に置さ，全身検索するべきである゙.

一般にうっ血と血流変化によるものを静脈血栓症, 静 脈壁の炎症性変化によるものを血栓性静脈炎と呼ぶが，
臨床的に両者を区別することは困難である ${ }^{4) 51}$. 自験例 では急性扁桃淡による淡症が副咽頭間隙へ波及乙, 内頸 静脈にまで炎症を及活し，2次的に血管内皮細胞を損傷 し発症に至ったものと考完られた。

臨床症状としては頸部の疼痛, 腫脹, 発赤, 発熱, 白 血球増多などの非特異的炎症兆候は認められるが，特徵 的な症状がないため，原疾患の症状に隠ぺいされ診断は 容易ではない68)、頸部痛犒よび下顎角あるいは胸鎖乳 突筋前縁に沿ら腫脹を認め, 敗血症や肺感染巣を伴う場

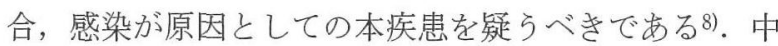
心静脈カテーテルが誘因となった症例の多くは不完全閉 塞で, 無症候である4)9.

本症の診断には CT, 超音波検査, MRI や血管造影な どが有用とされなかでも造影 CT の診断価值が高い. 典型例では静脈内腔の低濃度, 静脈壁に一致したリング 状増強执よび静脈桩張がみられる。リング状増強像は血 管壁の栄養血管 (vasa vasorum) の造影効果である10). ただし血栓形成初期では造影剤で濃染される血管と区別 がつきにくく，造影 CT のみでは静脈血栓の診断がつき にくい場合がある。その場合は単純 CT, あるいは超音 波検査の併用が鑑別に必要となる11)。また，陳旧性の血 栓では血栓とともに静脈自体も器質化し, 静脈壁の造影 効果がみられなくなる12)。今回，自験例に特いて邑同様 の現象を認めている.

超音波検査では，新鮮血栓は血液と同じ低ェコーとな るが，慢性期は血栓の器質化とともにエコー輝度が上昇 する。血栓により静脈環流の低下が起こるとバルサルバ 法による静脈桩張が消失し，また探触子で静脈を王迫し て完全に消失する場合には，血栓が存在しないと判断で さる.静脈血栓は静脈の圧迫不良か, あるいは血栓エコー の存在で診断するべきで，カラードップラーによる血流 の存在は血栓の存在を否定する根拠にはならないとされ る13)。超音波検査は静脈の閉塞状態やリンパ節との関係 をリアルタイムに観察でき，静脈を矢状断で追らことが できる点で有利であるが，下顎部，鎖骨下の観察が困難 である。

MRI では血栓は T1, T2 強調画像ともに高信号とし て描出されるが，血流が緩徐な場合も同様の所見となる ため他の検査が必要とされる5).

血管造影は血栓による静脈閉塞の範囲，側副血行路の 状況を知り得るのに有用である。選択的内頸静脈造影は 血栓遊離の危険性があるため, intravenous digital sub- 
traction angiography (IV-DSA) が推奨されているが14), 静脈が完全閉塞している場合, 正確な血栓の範囲が診断 できないことがある15).

内頸静脈血栓症の合併症として重要なのが肺塞栓症で ある. Lemierre's syndromeなどの敗血症性血栓性静脈 炎ではしばしば敗血症性肺塞栓症を合併する.敗血症性 塞栓症は血栓の一部が細菌あるいは真菌, 寄生虫などの 生物体を含んでいる場合に発生し ${ }^{16)}$, 肺のみならず関節, 骨, 䯣膜, 肝にも認める ${ }^{17}$. この塞栓子が肺に塞栓を起 こせば敗血症性肺塞栓症となるが，原因として自験例の ような血栓性静脈炎による敗血症のほかに感染性心内膜 炎や骨䯣炎によるものがある ${ }^{1618)}$. 敗血症性肺塞栓症に よる呼吸障害は重大で, とさに集中治療管理や人工呼吸 器による補助換気が必要になる ${ }^{19}$. 臨床兆候として胸痛, 呼吸困難等の呼吸障害, 喀血, 胸水, 膿胸がしばしばみ られるとされるが19), 自験例では軽度の酸素飽和度低下 のみで, 肺症状の増悪は認めなかった。

敗血症性肺塞栓症の CT の特徵として, (1)両側肺野に 円状結節が多発し, (2)楔状または辺縁膨隆状の結節が胸 膜に接するように存在し, (3)一部は肺血管の末梢に位置 し(feeding vessel sign), (4)結節内部は壊死によって空 洞を形成する (target sign) ${ }^{18200)}$. 原因菌として有名なる のにロ腔に常在する嫌気性菌である Fusobacterium necrophorum が挙げられる. 自験例では血液培養で口腔内常 在菌のStreptococcus intermedius が検出され，原因菌と 考光られ, 横山ら 21) も同菌による内頸静脈血栓症を報 告している.

内頸静脈血栓症の治療法は, 感染が背景にある場合に は抗生剤による治療が主流となっている，原因菌を同定 後, 感受性のある薬剤投与が原則だが, 日常臨床では原 因菌同定前に経験的治療 (empiric therapy) としての薬 剂投与が必要になる場面が多い.F. necrophorum が原 因菌であることを想定してペニシリン，クリンダマイシ ソ, メトロニダゾール, クロラムフェニュールや $\beta$ ラ クタマーゼ阻害薬配合剂の使用を推奨する報告がある が1917722), 本邦では保険適用の問題から，これらの抗生 剤による治療をそのまま適用するのは難しい，膿瘍を形 成している場合は手術的な排膿が適用される.

抗凝固剂の使用については賛否両論がある．感染性の 内頸静脈血栓症に対して抗生剂単独拉よび切開排膿の併 用のみでの治療が奏功した例も散見されるが1921), 抗凝 固剂の使用が血栓のさらなる増大を防ぎ, 肺塞栓症や敗
血症性塞栓症の発症の危険性を低下させるといら意見も 多(113). すなわち抗凝固剂は血栓増大の進行を抑兄, 肺塞栓症を予防する意味で使用されている. 血栓性静脈 炎や敗血症性塞栓症に対して抗凝固剂の有効性を調査し た対象研究はなされていないが1722)，Josey ら 23) は骨盤 の敗血症性血栓性静脈炎症例に対してへパリンを使用し， 早期の回復を認めたことを報告し, Lee ら ${ }^{22)}$ は禁忌が ない限りへパリンの使用を考慮するべきであると考察し

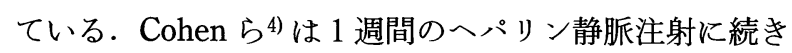
ワーファリン内服を行い, 抗凝固療法は 3 力月継続する ことを推奖している.

ウロキナーゼや t-PA (tissue plasminogen activator) 製剤などの血栓溶解剤は, 発症 4 日以上経過し器質化し 始めている血栓に効果は期待できず6), また溶解剂使用 時に合併症としての出血や遊離血栓による肺塞栓症誘発 といら危険性もあり24)，適応は限られる。

今回われわれは抗血小板剤である塩酸チクロピジンを 使用したが，抗血小板剤の使用に関してはいまだ議論も あり, 今後の課題である6).

手術療法として血栓静脈の近位側結紮や切除といら方 法も存在するが, 手術操作により血栓が移動し, 医原性 の肺塞栓を起こす危険性もあり625), 安易に行うべきで はなく, 抗生剂や抗凝固剤による保存的治療に抵抗性で, 反復性の肺塞栓症を認めた場合に適応となる17).

$$
\text { まとめ }
$$

1. 急性扁桃炎を契機として発症し, 敗血症性肺塞栓 症を合併した内頸静脈血栓症の 1 例を経験した.

2. 臨床症状として咽頭痛のほかに頸部腫脹や発熱を 認め, 診断に頸部造影 CT が有用であった.

3. 治療法として抗生物質に加兄, 抗凝固剂, 抗凝血 剂を使用し肺病変は消失したが, 血栓の器質化のため内 頸静脈の再開通はみられなかった。

4. 感染に伴う内頸静脈血栓症例に遭遇した場合, 敗 血症性肺塞栓症の合併も考虑し, 胸部単純 X線写真や胸 部 CT による検索が必要であると考光られた。

な拉，本論文の要旨は第 62 回耳鼻咽啹科臨床学会 $(2000$ 年 7 月 8 日, 福井)に扔いてロ演した.

\section{参考文献}

1) Kale US and Wight RG : Primary presentation of spon- 
taneous jugular vein thrombosis to the otolaryngologist ; in three different pathologies. J Laryngol Otol $112: 888$ $\sim 890,1998$.

2) Long JW : Excision of internal jugular vein. Surg Gynecol Obstet $14: 86 \sim 91,1912$.

3 ) Chowdhury K, Bloom J, Black MJ, et al. : Spontaneous and nonspontaneous internal jugular vein thrombosis. Head Neck 12 : 168 173, 1990.

4) Cohen JP, Persky MS and Reede DL : Internal jugular vein thrombosis. Laryngoscope $95: 1478 \sim 1482,1985$.

5 ) 北原伸郎, 伊藤 健, 田中利善, 他 : 悪性腫瘍リンパ節転 移による内頸静脈血栓症. 耳鼻臨床 $85: 1807 \sim 1813,1992$.

6 ) 菊池康隆, 富谷義徳, 関 哲郎, 他 : 内頸静脈血栓症の 2 症例. 耳展 $39: 396 \sim 404,1996$.

7 ) Amundsen MA, Spittell JA, Thompson JH, et al. : Hypercoagulability associated with malignant disease and with the postoperative state. Ann Intern Med 58 : 608 616, 1963.

8 ) Tovi F, Fliss DM and Noyek AM : Septic internal jugular vein thrombosis. J Otolaryngol $22: 415 \sim 420,1993$.

9 ) Rubenstein M and Creger WP : Successful streptokinase therapy for catheter ; induced subclavian vein thrombosis. Arch Intern Med $140: 1370 \sim 1371,1980$.

10) Zerhouni EA, Barth KH and Siegelman SS : Demonstration of venous thrombosis by computed tomography. Am J Roentgenol $134:$ 753 758, 1980.

11) Patel $S$ and Brennan $J$ : Diagnosis of internal jugular vein thrombosis by computed tomography. J Comput Assist Tomogr $5: 197 \sim 200,1981$.

12) Wen $\mathrm{BC}$ and Dolan $\mathrm{KD}:$ Computed tomography of internal jugular vein thrombosis. Ann Otol Rhinol Laryngol $98: 318 \sim 319,1989$.

13）応儀成二: 下肢深部静脈血栓症の診断と治療. 静脈学 9 : $263 \sim 270,1998$.

14）家根旦有, 田中 治: 内頸静脈血栓症の 1 症例. 耳展 31 : $357 \sim 362,1988$.
15）陣内 賢, 渡邊健一, 八木聰明, 他 : 内頸静脈血栓症の 1 例. 耳喉頭頸 $68: 982 \sim 985,1996$.

16) Fraser RS, Müller NL, Colman N, et al. : Thrombosis and thromboembolism. Fraser and Paré's Diagnosis of Disease of the CHEST. 4th ed, Vol III (ed by Fraser RS, Müller NL, Colman N, et al.). pp 1773 1843, WB Saunders, Philadelphia, 1999.

17) Lustig LR, Cusick BC, Cheung SW, et al. : Lemierre's syndrome ; two cases of postanginal sepsis. Otolaryngol Head Neck Surg $112: 767 \sim 772,1995$.

18）佐原 伸, 吉田和浩, 干野英明, 他：与歯が原因と考学ら れた敗血症性肺塞栓症の 1 例. 日胸 $57: 766 \sim 770,1998$.

19) Williams A, Nagy $M$, Wingate $J$, et al. : Lemierre syndrome ; a complication of acute pharyngitis. Int J Pediatr Otorhinolaryngol $45: 51 \sim 57,1998$.

20）塚田 博, 佐藤敏輝, 高木 聡, 他: Postanginal sepsis による pulmonary septic embolism の 1 例. 臨放 $42: 1717$ $\sim 1720,1997$.

21）横山真紀, 橋口一弘, 保谷則之 : 内頸静脈血栓症例. 耳鼻 臨床 $92: 1019 \sim 1023,1999$.

22) Lee BK, Lopez F, Genovese $M$, et al. : Lemierre's syndrome. South Med J $90: 640 \sim 643,1997$.

23) Josey WE and Staggers SR Jr : Heparin therapy in septic pelvic thrombophlebitis; a study of 46 cases. Am J Obstet Gynecol $120: 228 \sim 233,1974$.

24）佐戸川弘之, 星野俊一, 岩谷文夫, 他 : 下大静脈血栓症に 対する治療方針の検討. 静脈学 $7: 293 \sim 300,1996$.

25) Dorton HE : Internal jugular vein thrombosis with fatal iatrogenic pulmonary embolism ; a case report. Am Surg $41: 753 \sim 754,1975$.

$$
\left.\begin{array}{l}
\text { 原稿受付 : 平成 } 13 \text { 年 } 6 \text { 月 } 25 \text { 日 } \\
\text { 原稿採択 : 平成 } 13 \text { 年 } 7 \text { 月 } 11 \text { 日 } \\
\text { 別刷請求先 : 百島尚樹 } \\
\text { ₹060-8543 札幌市中央区南 } 1 \text { 条西 } 16 丁 \text { 丁 } 1 \\
\text { 札幌医科大学耳鼻咽喉科学教室 }
\end{array}\right)
$$

